\title{
State of the Art for Evaluation of Inventive Design Solution Concepts
}

\author{
Muhammad Irshad Yehya ${ }^{1(\bowtie)}$, Remy Houssin $^{2}$, Amadou Coulibaly $^{1}$, \\ and Hicham Chibane ${ }^{1}$ \\ ${ }^{1}$ ICUBE Laboratory-CSIP Team, INSA of Strasbourg, Strasbourg, France \\ muhammad.irshad_yehya@insa-strasbourg.fr \\ 2 ICUBE Laboratory-CSIP Team, University of Strasbourg, Strasbourg, France
}

\begin{abstract}
The concepts of solutions resulting from the inventive design process measures are generally described in a declarative manner, which does not allow having a shareable formal or visual representation between partners of the project. In addition, the absence of a model does not allow evaluation and compare competing concepts. In this paper, most relevant work regarding inventive design solution concept presented along with potential merits and demerits and highlighted the need of a systematic method to evaluate behavioral performance of solution concepts.
\end{abstract}

Keywords: Solution concept - Evaluation model of solution concepts · Inventive design · TRIZ

\section{Introduction}

In today's fast growing technological world companies, inventors and R\&D facing with new challenges regarding its capacity to quickly and accurately respond to society's development demands or problems. To cope with the acceleration of new artefacts' demand, innovative activities need to be more assured in terms of optimal solution with respect to many aspects (functionality, maintainability, reliability, security, cost, quality, etc.) [1].

Ideas are defined in two ways i.e. useful or not useful. New ideas which are useful, constructive and profitable or solve a problem are referred as creative ideas while only fancy, not realistic and not useful ideas called mistakes [2]. With reference to the inventive design techniques like TRIZ (theory of inventive problem solving) where ideas are defined more properly than conventional terms of creative activities. After going through properly defined process, creative idea is called "Solution concept" [3]. A solution concept should be taken as an idea which has its all necessary information or characteristics most probably documented in sufficient details for an artefact (concrete way with a description template) so that an objective estimation becomes possible. In inventive design when ideas are characterized in a concrete way with description template, the concepts called Solution Concepts. 
Inventive design is the field which develops methodologies for problem solution regarding the development of innovative artefacts [4]. There are many methods created which are able to successfully carry out inventive design steps to produce solution concepts or ideas and solution concept ranking processes [5]. However has the drawback "inability to evaluate optimum solution concept". Herstatt highlighted the inability of routine design methods for creating inventive ideas [6].

\section{Aim and Scope}

The aim of this research is to identify, interpret and summaries the literature currently available on evaluation of inventive design solution concepts. Within the scope of this research, the focus has been on relevant research articles, and other authentic literature specifically for evaluation of solution concepts.

\section{Inventive Design Solution Concepts}

\subsection{Inventive Design Definition}

Several attempts have been made to define inventive design by both scientific and artistic terms. Inventive design is a thought-provoking engineering activity associated to all areas of human life. It follows the laws of science, fulfill the requirements for realization of a solution concept and needs professional integrity and responsibility. It is an attempt to possible realization of concepts by meeting particular constraints [2]. Inventive design is acquisition of knowledge and capitalization [7]. Inventiveness here is in terms of invention which means "the action of creating or designing (something that has not existed before), typically a process or device" [8]. T. Chikatham one of the authors [2] compared inventive design and routine design as given in Table 1: In Inventive Design, the contradicted features of a situation or problem by TRIZ tools is highlighted and these contradictions are then considered as a key source to solve problem [9].

Table 1. Inventive design vs routine design [2]

\begin{tabular}{l|l}
\hline Routine design & Inventive design \\
\hline Manage what is known & Discover what is unknown \\
\hline Optimization of existing data for best result & $\begin{array}{l}\text { Moving further ahead from the optimized result } \\
\text { of existing data }\end{array}$ \\
\hline Accept compromise as a potential solution & Refuse compromise as a possible solution \\
\hline
\end{tabular}




\subsection{Our Position in Inventive Design Process}

The first article on TRIZ was by Genrich Altshuller in 1956 [10]. Its application has been observed in various fields like technic, management, sociology, education and marketing [11]. During 80s Altshuller work developed into a set of tools to carryout systematic creativity called TRIZ "Theory of inventive problem solving" and in 90s to OTSM "General theory of strong thinking" and ZhSTL "Lifetime strategy for creative person" [10]. The research progress in field of TRIZ as a result gave rise to organized data in order to understand TRIZ and its extension as IDM (Inventive Design Method).

The Inventive Design Method is the output of many years of research by INSA Strasbourg France [12]. With the intention to build an abstract model with initial problem formulation using the theoretical approach of TRIZ C. Zanni Merk [7] proposed an ontology for computer based innovation. In further progress of TRIZ, Francois Rousselot [13] proposed an important formal definition of contradiction and its possible applications in inventive design with respect to the TRIZ fundamentals. Following the previous work the extension of TRIZ called inventive design method IDM proposed and developed and framed into a computer software named STEPS by INSA Strasbourg [14]. Currently there are different TRIZ based computer-aided innovation (CAI) systems, which support design phase inventive design [15]. These CAI systems provide suitable tools for designer to generate solution concepts and their rankings on the basis of multi criteria decision methods but still lack in evaluation of generated solution concepts. Keeping all these in consideration our focus will be regarding need of a confident evaluation model along with specific criteria (quality, maintainability etc.) of solution concepts, which come from the previous steps of inventive design using different TRIZ tools and methods.

Inventive design can be subdivided into four main steps shown in Fig. 1: initial situation analysis, contradiction formulation, solution concept generation, and solution concept selection or evaluation of solution concepts [5].

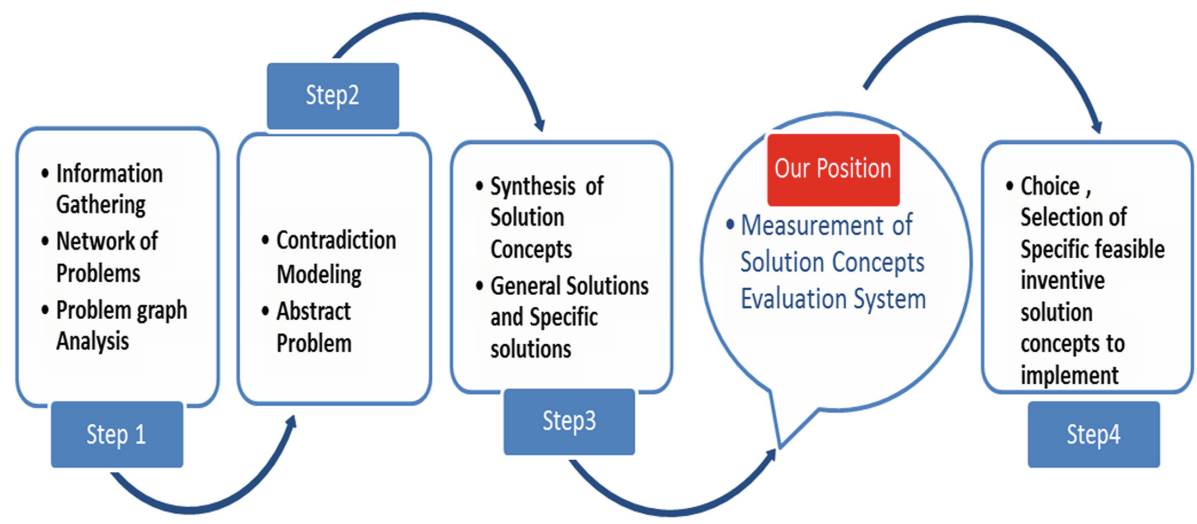

Fig. 1. Inventive design solution concepts evaluation status 
The primary steps of inventive design development known by the term 'concept development'. Concept development contains a sequences of divergent steps and convergent steps, completed at different levels of solution concept [16]. In concept development, generation of solution concepts belongs to divergent steps while evaluation and selection of the best solution concepts are related to convergent steps.

\subsection{Inventive Design Solution Concept Evaluation}

A concept of any product is a predicted representation of the shape of product, its working standards and technology. It is a well explained definition of product characteristics that how the product will satisfy the voice of customer. Generally a concept is considered as a sketch or 3D model following a detail description. The success of any product depends on the selection of best concept. Success here means the commercialization of the quality product.

With reference to inventive design solution concepts, the arrival of TRIZ and its extension to IDM has been considered as a systematic methodology to produce set of solution concepts as compared to earlier unstructured methods [17]. As mentioned in the introduction that a solution concept should be describe in a concrete way with a description template. The description template for solution concept characterizes into five categories [13]. These five categories are: 1) an abstract of idea describing the general properties, all the relevant performing functions, extra note, merits/demerits. 2) A complete explanation of problem model (in which contradiction contain action parameter and evaluation parameter or SU-field model) and solution model (using tools like inventive principle, inventive standard, physical effect database). 3) Possible outcomes, trends and developments from the outcomes of related projects in term of hypothesizes and laws of technical systems evolution, 4) keeping the objective of the project point out all the inacceptable conditions. 5) A sketch of the solution concept, which is synthesized by model of solution and hypothesis of solution concept. After the set of solution concepts are identified and ranked using Pugh matrix by the inventive design methodology for the next step to select the solution concept to develop or solution concept evaluation.

The evaluation phase of solution concept is the key challenge for the designers, as well as the customers. Particularly in solution concept selection phase qualitative methods are used to evaluate the generated solution concepts. Although, to facilitate the inventive design solution concepts evaluation steps, there are many methodologies used by designers and customers $[14,19]$. However, these methodologies are generally described in a qualitative, declarative manner, which does not allow to choose the best solution concept neither to have a shareable formal or visual representation between partners of the project. In inventive design the process stops after ranking of solution concepts and final selection of solution concept to develop depends on R\&D or the top management of company. That is why, the absence of a confident model does not allow evaluation and compare competing concepts thereby making a challenge for researchers and designers to develop a confident model for evaluation of inventive design solution concepts. 


\subsection{Research Gaps in Inventive Design Solution Concept Evaluation}

In this section, an overview of the most prominent research work regarding inventive design solution concept is given in the Table 2 . The purpose of this research is to highlight the need for inventive design solution concepts evaluation model.

Table 2. Literature review on inventive design solution concepts

\begin{tabular}{|c|c|c|c|c|}
\hline Title of paper & Focus area & Research gap & Ref. & Year \\
\hline $\begin{array}{l}\text { Improving Inventive } \\
\text { Design Methodology's } \\
\text { Agility }\end{array}$ & $\begin{array}{l}\text { Focus on elimination of } \\
\text { non-value added } \\
\text { activities to reduce long } \\
\text { time taking in inventive } \\
\text { design solution concepts } \\
\text { process }\end{array}$ & $\begin{array}{l}\text { After solution concepts } \\
\text { making the final selection } \\
\text { depends on the R\&D or } \\
\text { decision makers of } \\
\text { company, no semantic } \\
\text { model available for } \\
\text { evaluation of solution } \\
\text { concepts }\end{array}$ & [20] & 2019 \\
\hline $\begin{array}{l}\text { Contribution to } \\
\text { Formalizing Links } \\
\text { Between Invention and } \\
\text { Optimization in the } \\
\text { Inventive Design Method }\end{array}$ & $\begin{array}{l}\text { Prevention of rejection of } \\
\text { good solution concepts at } \\
\text { early phases of inventive } \\
\text { design and ranking of } \\
\text { solution concepts for } \\
\text { decision makers to select }\end{array}$ & $\begin{array}{l}\text { Need for quantitative } \\
\text { evaluation method to give } \\
\text { adequate confident to } \\
\text { decision makers regarding } \\
\text { selection of solution } \\
\text { concept to develop }\end{array}$ & {$[2]$} & 2017 \\
\hline $\begin{array}{l}\text { An Approach to Identify } \\
\text { the Readiness Level of a } \\
\text { Solution Concept in the } \\
\text { Inventive Design Method }\end{array}$ & $\begin{array}{l}\text { Solution Concept } \\
\text { Feasibility }\end{array}$ & $\begin{array}{l}\text { Selection of Solution } \\
\text { concept depends of } \\
\text { expertise of decision } \\
\text { maker }\end{array}$ & {$[3]$} & 2016 \\
\hline $\begin{array}{l}\text { On Solution Concept } \\
\text { Evaluation/Selection in } \\
\text { Inventive Design }\end{array}$ & $\begin{array}{l}\text { Improve early decision } \\
\text { processes for feasibility } \\
\text { of solution concepts }\end{array}$ & $\begin{array}{l}\text { Lack of evaluation or } \\
\text { selection method for } \\
\text { solution concepts }\end{array}$ & {$[14]$} & 2015 \\
\hline $\begin{array}{l}\text { A Software Framework } \\
\text { to Support Engineering } \\
\text { Analysis for Inventive } \\
\text { Solution Concepts }\end{array}$ & $\begin{array}{l}\text { Pre dimensioning and } \\
\text { feasibility criteria of } \\
\text { solution concept }\end{array}$ & $\begin{array}{l}\text { No proper facility for } \\
\text { solution concept selection }\end{array}$ & {$[21]$} & 2015 \\
\hline $\begin{array}{l}\text { Towards a formal } \\
\text { definition of } \\
\text { contradiction in inventive } \\
\text { design }\end{array}$ & $\begin{array}{l}\text { Formalization of } \\
\text { contradictions to reach } \\
\text { relevant solution concept } \\
\text { synthesis stage }\end{array}$ & $\begin{array}{l}\text { After Ranking of Solution } \\
\text { concepts using Pugh } \\
\text { Matrix, final selection } \\
\text { depends on R\&D or top } \\
\text { management of company } \\
\text { and no confident model } \\
\text { for evaluation of solution } \\
\text { concepts }\end{array}$ & {$[13]$} & 2012 \\
\hline $\begin{array}{l}\text { A research agenda for } \\
\text { computing developments } \\
\text { associated with } \\
\text { innovation pipelines }\end{array}$ & $\begin{array}{l}\text { Computer added } \\
\text { innovation and future } \\
\text { agenda proposal }\end{array}$ & $\begin{array}{l}\text { Need innovative methods } \\
\text { for concept selection and } \\
\text { solution concept } \\
\text { evaluation }\end{array}$ & {$[22]$} & 2011 \\
\hline
\end{tabular}


Table 2. (continued)

\begin{tabular}{l|l|l|l|l}
\hline Title of paper & Focus area & Research gap & Ref. & Year \\
\hline $\begin{array}{l}\text { Monitoring the Impact of } \\
\begin{array}{l}\text { Solution Concepts within } \\
\text { a Given Problematic }\end{array}\end{array}$ & $\begin{array}{l}\text { Using Pugh's approach } \\
\text { for qualitative evaluation } \\
\text { of concepts of for } \\
\text { producing solution } \\
\text { concepts }\end{array}$ & $\begin{array}{l}\text { After given list of solution } \\
\text { concepts the method stops } \\
\text { further input in selection } \\
\text { of solution concepts }\end{array}$ & [23] & 2009 \\
\hline
\end{tabular}

Not every method is used in every inventive design process. Only those that seem appropriate for the problem situation and that contribute to a successful outcome are used. Based on the most relevant and latest research articles considered in this state of the art, we clearly identify the research gap regarding evaluation of inventive design solution concepts. More clearly stating that there is not any certain tool, model etc., for evaluation of solution concepts in inventive design to suggest a specific solution in the solution concept building phase or solution evaluation phase as showing our position in Fig. 1.

\section{Conclusion and Future Research}

Instead of all the features included in the IDM there is still a gap in providing a model to the best selection of solution concept. The evaluation of solution concepts is no doubt the most important step of inventive design process because of its effect on all following steps in terms of performance, quality, maintainability, cost, safety, etc., of the selected solution concept for development. As it is obvious that failure of a selected solution concept for development can barely be compensated at next phases of advance design and development by resulting long time of redesign and rework expense. According to S.R Daly [24] almost $80 \%$ of the cost is committed at solution concept selection phase and figured out that $80 \%$ of a manufactured product's cost occur during the process of product design.

To date most of research in inventive design has been made in from the very beginning steps to solution concept ranking. One of the toughest, critical and complex problems in inventive design process is the evaluation of best solution concept to go for manufacture or implement [24]. Following the research gaps through this research, we are considering to propose a semantic modeling approach and method to evaluate behavioral performance of solution concepts in inventive design along with the proper definition of solution concept.

\section{References}

1. Okudan, G.E., Tauhid, S.: Concept selection methods \& ndash; a literature review from 1980 to 2008. Int. J. Des. Eng. 1(3), 243 (2008)

2. Chinkatham, T.: Contribution of the formulation of the links between Invention - Optimization in Inventive conceptual design To cite this version (2017) 
3. Chinkatham, T., Souili, A., Taheri, A., Cavallucci, D.: An approach to identify the readiness level of a solution concept in the inventive design method. Procedia CIRP 39, 179-184 (2016)

4. Yan, W., Zanni-Merk, C., Rousselot, F.: Matching of different abstraction level knowledge sources: the case of inventive design. In: Lecture Notes Computer Science (including Subseries Lecture Notes Artificial Intelligence Lecture Notes Bioinformatics), vol. 6884, LNAI, no. PART 4, pp. 445-454 (2011)

5. Shah, J.J., Kulkarni, S.V., Vargas-Hernandez, N.: Evaluation of idea generation methods for conceptual design: effectiveness metrics and design of experiments. J. Mech. Des. Trans. ASME 122(4), 377-384 (2000)

6. Herstatt, P.C.: The 'Fuzzy Front End' of innovation, no. 4, pp. 1-24 (2001)

7. Zanni-Merk, C., Cavallucci, D., Rousselot, F.: An ontological basis for computer aided innovation. Comput. Ind. 60(8), 563-574 (2009)

8. Oxford Lexico Dictionary. https://www.lexico.com/en/definition/invention

9. Altshuller, G., Al'tov, G., Altov, H.: And Suddenly the Inventor Appeared: Triz, The Theory of Inventive Problem Solving. Technical Innovation Center, Inc, Worcester (1996)

10. Altshuller, G.S., Shapiro, P.B.: On the psychology of inventive creativity. Moscow (1956)

11. Ilevbare, I.M., Probert, D., Phaal, R.: A review of TRIZ, and its benefits and challenges in practice. Technovation 33(2-3), 30-37 (2013)

12. Cavallucci, D., Strasbourg, I.: From TRIZ to inventive design method (IDM): towards a formalization of inventive practices in R \& D departments, 2-3 (2012)

13. Rousselot, F., Zanni-Merk, C., Cavallucci, D.: Towards a formal definition of contradiction in inventive design. Comput. Ind. 63(3), 231-242 (2012)

14. Chinkatham, T., Cavallucci, D.: On solution concept evaluation/selection in inventive design. Procedia Eng. 131, 1073-1083 (2015)

15. Innvention-machine. http://invention-machine.com/factsheet_GoldfireInnovator.html

16. Backhouse, C.J.: A review of: 'Total Design.' By STUART PUGH. (Addison Wesley, 1991) [Pp. 278] Paperback, £16.95. Level: Designer/design lecturer. Int. J. Comput. Integr. Manuf. 4(5), 321 (1991)

17. Altshuller, G.S.: To find an idea, Introduction to theory Invention Problem solving.Novosibirsk. Nauk. Publ. (1986)

18. Chinkatham, T., Cavallucci, D.: Early feasibility evaluation of solution concepts in an inventive design method framework: approach and support tool. Comput. Ind. 67, 1-16 (2015)

19. Stalnaker, R.: On the evaluation of solution concepts. Theory Decis. 37(1), 49-73 (1994)

20. Hanifi, M., Chibane, H., Houssin, R., Cavallucci, D.: Improving inventive design methodology's agility. In: International TRIZ Future Conference, pp. 216-227 (2019)

21. Chinkatham, T., Cavallucci, D., Knittel, D.: A software framework to support engineering analysis for inventive solution concepts. Procedia Eng. 131, 626-634 (2015)

22. Cavallucci, D.: A research agenda for computing developments associated with innovation pipelines. Comput. Ind. 62(4), 377-383 (2011)

23. Cavallucci, D., Rousselot, F., Zanni, C.: Monitoring the impact of solution concepts within a given problematic. IFIP Adv. Inf. Commun. Technol. 304, 1-8 (2009)

24. Daly, S.R., Yilmaz, S., Christian, J.L., Seifert, C.M., Gonzalez, R.: Design heuristics in engineering. J. Eng. Educ. 101(4), 601-629 (2012) 
Open Access This chapter is licensed under the terms of the Creative Commons Attribution 4.0 International License (http://creativecommons.org/licenses/by/4.0/), which permits use, sharing, adaptation, distribution and reproduction in any medium or format, as long as you give appropriate credit to the original author(s) and the source, provide a link to the Creative Commons license and indicate if changes were made.

The images or other third party material in this chapter are included in the chapter's Creative Commons license, unless indicated otherwise in a credit line to the material. If material is not included in the chapter's Creative Commons license and your intended use is not permitted by statutory regulation or exceeds the permitted use, you will need to obtain permission directly from the copyright holder. 